\title{
ANALISIS PENERIMAAN MAHASISWA TERHADAP SISTEM INFORMASI AKADEMIK (SIAKAD) DENGAN METODE TECHNOLOGY ACCEPTANCE MODEL (TAM)
}

\author{
Dison Librado \\ Program Studi Teknik Informatika STMIK AKAKOM \\ Jl. Raya Janti no. 143, Yogyakarta \\ Email: disonlibrado@gmail.com
}

\section{ABSTRACT}

Computer based data processing is expected to improve user performance, but the computer was not completely accepted by individuals. STMIK AKAKOM in one of their activities applied information technology to SIAKAD that provides some features for learning activities on campus

The analysis of SIAKAD acceptance by students using the technology acceptance model (TAM), with partial least square, is to know how the behavior of SIAKAD users as the end user? It would be related to usefulness (PU), ease of use (PEOU), attitude toward using (ATU), and behavioral intention to use (BITU).

From the analysis of data, the results is mention that there were a positive and significant influence between the variables. Technology acceptance factors that inflict attitude to use SIAKAD by student in their learning activities is the ease of use and usefulness )

Keyword: attitude, ease of use, intention, SIAKAD, TAM, usefulness

\section{PENDAHULUAN}

Penerapan teknologi dalam berbagai bidang telah menjadi hal yang biasa dijumpai, karena teknologi itu dipandang sebagai alat bantu yang dapat memudahkan pekerjaan manusia. Meningkatnya kebutuhan informasi mengakibatkan meningkatnya kebutuhan akan pengembangan sistem informasi. Dalam menjalankan kegiatannya, organisasi selalu diharuskan untuk mengatur proses yang terjadi mulai dari pengumpulan, pemilahan, pemasukan, dan pengolahan data, hingga penyimpanan, dan penyampaian informasi dari aktivitasnya sehari-hari.

Pengolahan data dengan bantuan komputer diharapkan dapat meningkatkan kinerja pemakainya. Kehadiran komputer tidak sepenuhnya diterima secara positif oleh setiap individu. Keberadaan komputer belum tentu dapat dirasakan manfaatnya oleh setiap pemakainya (Thompson dalam Sekundera, 2006). Teknologi dinilai tidak selalu dapat memenuhi kebutuhan pemakai, karena tidak selalu 


$\begin{array}{lcr}\text { mendatangkan } & \text { kemudahan } & \text { bagi } \\ \text { pemakainya, } & \text { bahkan } & \text { dapat } \\ \text { mendatangkan } & \text { kesulitan } & \text { bagi } \\ \text { pemakainya. } & \text { Padahal } & \text { teknologi }\end{array}$

komputer memiliki potensi untuk memperbaiki kinerja sehingga organisasi mau melakukan investasi untuk berbagai aplikasi komputer. Di sisi lain, manfaat potensial komputer untuk membantu dalam pembuatan keputusan manajerial belum secara penuh dapat direalisasikan karena tingkat penerimaan (acceptance) yang rendah dari pemakainya. Beberapa model telah dibangun untuk menganalisis dan memahami faktorfaktor yang mempengaruhi diterimanya penggunaan teknologi komputer.

STMIK AKAKOM adalah salah satu perguruan tinggi swasta yang berada di wilayah KOPERTIS V, Daerah Istimewa Yogyakarta. Kompetensi bidang ilmu yang diajarkan adalah Teknologi Informasi. Tentu dalam kesehariannya kebanyakan pekerjaan dan materi pembelajaran didistribusikan menggunakan peralatan komputer. Salah satu penerapan teknologi informasi pada bidang akademik sistem informasi akademik berbasis teknologi internet yang dinamai SIAKAD. Sistem ini menyediakan fitur-fitur yang diperlukan dalam proses pembelajaran di kampus, seperti untuk pengurusan KRS (kartu rencana studi), pengunduhan materi kuliah, informasi mata kuliah, dan informasi nilai mahasiswa. Pemanfaatan teknologi informasi merupakan sarana penunjang dalam mencapai tujuan organisasi. Pemanfaatan ini dapat dilakukan secara efektif jika anggota organisasi memiliki kemampuan dan keahlian dalam mengunakan teknologi itu dengan baik. Dengan demikian diperlukan usaha-usaha untuk mengetahui faktor-faktor apa saja kah yang mempengaruhi penerimaan SIAKAD, dengan menggunakan salah satu model untuk penerimaan teknologi yaitu Technology Acceptance Model (TAM). Penggunaan metode TAM ini didasarkan pada pernyataan Davis (2000), bahwa sejauh ini TAM merupakan konsep yang dianggap paling baik di dalam menjelaskan perilaku pengguna terhadap sistem teknologi informasi baru. Secara empiris terbukti bahwa TAM dapat menjelaskan $40 \%$ niat perilaku untuk menggunakan (behavior intension to use) (Davis, 2000).

Dengan latar belakang tersebut dapat dirumuskan permasalahan yaitu 
bagaimanakah perilaku pemakai SIAKAD sebagai pemakai akhir dalam menghadapi masalah dan kesulitan dalam penggunaan sistem? Hal tersebut akan berhubungan dengan Kemanfaatan (usefulness), Kemudahan Penggunaan (ease of use), sikap yang mengarahkan penggunaan (attitude toward using), dan niat perilaku menggunakan (behavioral intention to use) dari pemakai akhir dalam menggunakan SIAKAD. Berdasarkan model TAM nantinya dapat diketahui bahwa aspek keperilakuan pemakai turut mempengaruhi persepsi dan sikap dalam menerima penggunaan teknologi informasi dengan variabel kemanfaatan (usefulness) dan kemudahan penggunaan (ease of use). Tujuannya adalah untuk mengetahui seberapa jauh penerimaan mahasiswa pada Sistem Informasi Akademik (SIAKAD) yang telah dikembangkan dalam bentuk sistem informasi dengan memanfaatkan teknologi informasi berbasis web dan internet.

Titik awal paling baik untuk mempelajari faktor-faktor penentu perilaku individu pada umumnya adalah dari Theory of Reasoned Action / TRA (Fishbein dan Azjen, 1975), selanjutnya model yang disusun oleh Davis (1989) yaitu Technology Acceptance Model (TAM) untuk menjelaskan penerimaan teknologi yang akan digunakan oleh pengguna teknologi. TAM ini mendasarkan pada TRA, yang mengidentifikasi dua factor kunci pendahulu, yaitu Persepsi Kemudahan Penggunaan (Perceived Ease of Use / $P E O U$ ) dan Persepsi Kegunaan (Perceived Usefulness / PU) bagi pengguna dalam menerima dan menerapkan teknologi. TAM menghipotesiskan bahwa sikap pengguna terhadap teknologi ditentukan oleh Persepsi Kemudahan Penggunaan (Perceived Ease of Use) dan Persepsi Kegunaan (Perceived Usefulness) dari teknologi tersebut yang akan mempengaruhi niat mereka untuk menggunakan teknologi tersebut (Intention to Use). Secara empiris prediksi dari Persepsi Kemudahan Penggunaan (Perceived Ease of Use) dan Persepsi Kegunaan (Perceived Usefulness) pada penerimaan teknologi individu telah terbukti dan dikonfirmasi oleh berbagai penelitian (Lee dkk.., 2003).

Selain itu, TAM juga menyatakan bahwa Persepsi Kemudahan Penggunaan (Perceived Ease of Use) mempengaruhi Persepsi 
Kegunaan (Perceived Usefulness) karena sesuatu yang dipersepsikan lebih mudah digunakan akan lebih bermanfaat. Niat untuk menggunakan teknologi itu dapat dipengaruhi oleh banyak variable eksternal. Persepsi mengenai kemudahan dan kegunaan teknologi menjadi perantara terhadap pengaruh variabel eksternal pada sikap dan niat untuk menggunakan teknologi. Tujuan model TAM adalah untuk menjelaskan faktor-faktor utama dari perilaku pengguna terhadap penerimaan pengguna teknologi. Gambar 1 menunjukkan model penerimaan teknologi tersebut. Mulyani (_) ingin memperoleh bukti empiris terkait penerimaan teknologi Student Information Terminal (S-IT) dari penggunaan kerangka model TAM dengan variabel eksternal desain portal, organisasi e-resources, dan user abilities dan skill. Hasil pengujiannya menunjukkan ada dan tidaknya pengaruh antar variabel yang ditelitinya. Soenhadji dkk. (2008), memprediksi keyakinan mahasiswa akan manfaat fasilitas Studentsite dengan pendekatan Technology Acceptance Model. Tujuannya untuk memprediksi keyakinan mahasiswa dan menganalisis pemanfaatan fasilitas studentsite dengan pendekatan model Technology Acceptance (TAM). Hasil independen sample test mengarah pada penetapan variabel PEOU (sig.0,003) Dengan demikian variabel tersebut dapat menentukan keyakinan mahasiswa. Pengujian analisis diskriminan menghasilkan group covariance matrices (sig 0,985). Hasil predicted group membership secara umum menjelaskan keyakinan mahasiswa akan manfaat fasilitas studentsite sebesar 54 persen.

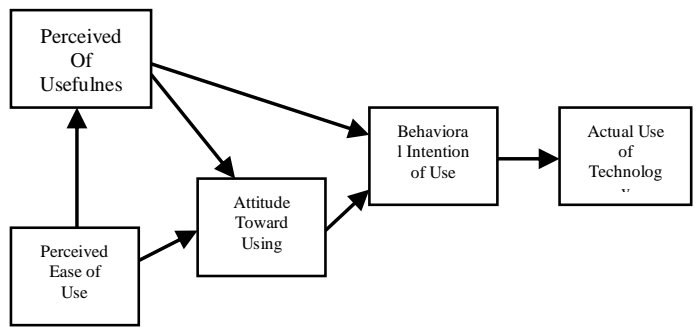

Gambar 1. Technology Acceptance Model / TAM (Davis, 1989)

Yanti (2012) meneliti tentang pertumbuhan internet yang cukup baik di Indonesia perlahan berperan dalam meningkatkan budaya belanja melalui internet (online shopping) di Indonesia. Tujuan penelitian ini adalah untuk menganalisis faktor-faktor penerimaan teknologi terhadap niat konsumen untuk berbelanja kembali melalui internet serta menganalisis pengaruh variabel moderasi yaitu sikap konsumen terhadap internet dalam menimbulkan 
niat konsumen untuk berbelanja kembali melalui internet.

Persepsi tentang kemudahan penggunaan suatu teknologi didefinisikan dengan ukuran kepercayaan seseorang pada komputer bahwa komputer ini dapat dengan mudah dipahami dan digunakan (Davis, 1989). Hipotesis yang dapat dikembangkan untuk menguji preposisi H1 (Hipotesis 1) adalah tingkat Persepsi Kemudahan Penggunaan (PEOU) SIAKAD akan mempengaruhi secara positif pada Persepsi Kegunaannya (PU) Pengguna dapat mengembangkan sikap negative terhadap sistem ketika mereka menjadi frustrasi karena kesulitan menggunakan sistem (Dennis dkk., 2009). Sikap mahasiswa untuk menggunakan SIAKAD semakin besar kemungkinannya terhadap teknologi yang lebih mudah. Hipotesis yang dapat dikembangkan untuk menguji preposisi H2 (Hipotesis 2) adalah tingkat Persepsi Kemudahan Penggunaan (PEOU) SIAKAD akan mempengaruhi secara positif pada Sikap yang Mengarahkan Penggunaannya (ATU).

Persepsi terhadap kemanfaatan didefinisikan sebagai suatu ukuran penggunaan suatu teknologi yang dipercaya akan mendatangkan manfaat bagi orang yang menggunakannya (Davis, 1989). Kekuatan untuk menarik pengguna terletak pada manfaat dan kegunaan teknologi, dan ia mendefinisikan Persepsi Kegunaan (Perceived Usefulness / PU) sebagai keyakinan bahwa menggunakan aplikasi akan meningkatkan kinerja seseorang (Davis, 1989). Hipotesis yang dapat dikembangkan untuk menguji preposisi H3 (Hipotesis 3) adalah H3 tingkat Persepsi kegunaan (PU) SIAKAD oleh mahasiswa akan mempengaruhi secara positif pada Sikap yang Mengarahkan Penggunaannya (ATU).

Attitude Toward Using dalam TAM dikonsepkan sebagai sikap terhadap penggunaan sistem yang berbentuk penerimaan atau penolakan sebagai dampak bila seseorang menggunakan suatu teknologi dalam pekerjaannya (Davis, 1989). Sikap orang memasukkan ke dalam kerangka pikiran untuk menyukai atau tidak menyukai sesuatu hal, untuk menggunakan atau tidak menggunakan internet (Petty dkk.., 1991). Berdasarkan konsep itu akan dikembangkan hipotesis untuk preposisi H4 (Hipotesis 4) yaitu Sikap yang Mengarahkan Penggunaan (ATU) 
SIAKAD akan mempengaruhi secara positif pada Niat Perilaku Menggunakannya (ITU). Behavioral Intention to Use adalah kecenderungan perilaku untuk tetap menggunakan suatu teknologi. Tingkat penggunaan sebuah teknologi komputer pada seseorang dapat diprediksi dari sikap perhatiannya terhadap teknologi tersebut, misalnya keinginanan menambah peripheral pendukung, motivasi untuk tetap menggunakan, serta keinginan untuk memotivasi pengguna lain (Davis, 1989).

\section{METODE PENELITIAN}

Penelitian ini akan menunjuk mahasiswa sebagai objek penelitian yang berperan sebagai pengguna akhir Sistem Informasi Akademik (SIAKAD). Untuk memperoleh tanggapan dari responden, maka dari populasi mahasiswa tersebut akan diambil beberapa sampel sebagai responden. Sampling adalah suatu cara pengumpulan data yang sifatnya tidak menyeluruh, artinya tidak mencangkup seluruh objek penelitian (populasi), tetapi hanya sebagaian dari populasi saja (yang menjadi sampel) yang diambil dari populasi tersebut (Supranto, 1981). Data yang akan diperoleh merupakan data primer yang diperoleh dari jawaban responden terhadap kuesioner yang disampaikan secara langsung kepada pengguna akhir. Penelitian ini akan menggunakan teknik survey, yaitu yang dilakukan dengan menyebarkan kuesioner. Setelah penyebaran kuesioner, diharapkan dapat kembali sesuai dengan jumlah yang diharapkan.

Sebelum dilakukan pengujian hipotesis dari data yang diperoleh digunakanlah model empiris. Koefisienkoefisien dalam model empiris ini menunjukkan hubungan kausal antar variabelnya. Hubungan kausal ini mewakili hipotesis-hipotesis yang telah dibuat dan akan diuji. Berikut ini adalah model empiris yang digunakan.

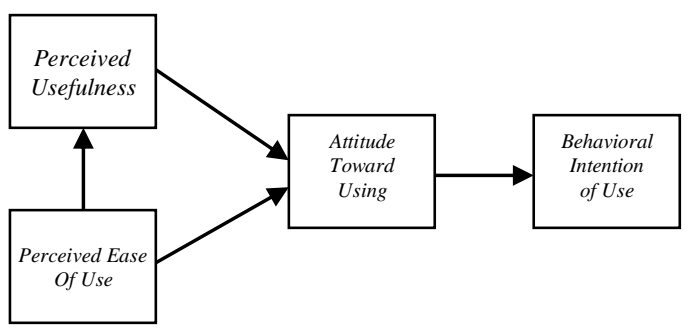

Gambar 2 Model Empiris Penelitian

Selanjutnya akan dilakukan dua macam pengujian yaitu pengujian instrumen penelitian dan pengujian terhadap hipotesis yang ada. Dalam Kartika (2013), Cooper menyatakan jika pengujian instrument merupakan pengujian yang dilakukan pada instrumen penelitian. Data penelitian 
yang diperoleh tidak akan memberikan manfaat apabila instrumen yang digunakan untuk mengumpulkan data penelitian tidak memiliki reliabilitas dan validitas yang tinggi. Oleh karena itu dalam hal ini akan dilakukan pengujian terhadap validitas dan reliabilitas data yang diperoleh

Uji validitas akan berhubungan dengan ketepatan alat ukur untuk melakukan tugasnya mencapai sasaran (Jogiyanto, 2008), yang dikelompokkan menjadi dua yaitu validitas isi (content validity) dan validitas konstruk. Uji Reliabilitas adalah untuk mengetahui tingkat seberapa besar suatu pengukur mengukur dengan stabil dan konsisten (Jogiyanto, 2008). Suatu konstruk dianggap reliabel apabila nilai composite reliabilitynya di atas 0,7, namun demikian pada riset pengembangan skala loading 0,5 sampai 0,6 masih dapat diterima (Ghozali, 2012).

Uji hipotesis akan dilakukan dengan alat analisis Partial Least Square (PLS), yang secara simultan dapat melakukan pengujian model pengukuran (Outer model) sekaligus pengujian model struktural (Inner model). Outer model digunakan untuk uji validitas dan reliabilitas, sedangkan inner model digunakan untuk uji kausalitas (pengujian hipotesis dengan model prediksi) (Jogiyanto dan Abdillah, 2010:14). Teknik ini menggunakan statistika multivariat yang akan membandingkan antara variabel dependen berganda dengan variabel independen berganda. Model evaluasi PLS mendasarkan pada pengukuran prediksi yang bersifat nonparametrik. Evaluasi dengan model PLS dilakukan dengan mengevaluasi outer model dan inner model.

Model struktural dievaluasi dengan menggunakan $\mathrm{R}^{2}$ untuk konstruk dependen, nilai koefisien path atau $t$-values tiap path diuji signifikansi antar konstruk dalam model struktural. Semakin tinggi nilai $\mathrm{R}^{2}$ maka semakin baik model prediksi dari model penelitian tersebut, tetapi $\mathrm{R}^{2}$ tidaklah menjadi satu-satunya parameter yang absolute dalam mengukur kepetapan model prediksi karena dasar hubungannya adalah parameter yang paling utama yang dapat menjelaskan hubungan kausalitas tersebut. Nilai koefisien path atau inner model menunjukkan tingkat signifikansi dalam pengujian hipotesis. Nilai koefisien yang ditunjukkan dari T-statistic harus $>1,96$ untuk hipotesis two tail atau $T$ - 
statistic $>1,64$ untuk hipotesis one tail pada alpha $5 \%$ dan power $80 \%$ (Hair dkk.., 1998)

\section{HASIL DAN PEMBAHASAN}

Sebelum melakukan pengujian terhadap model terlebih dulu dilakukan model pengukuran untuk uji validitas konstruk dan reliabilitas. Validitas harus diuji agar dapat diketahui kemampuan instrument penelitian ini dalam mengukur hal-hal yang ingin diukur. Selanjutnya pengujian reliabilitas dilakukan untuk mengukur konsistensi alat ukur dan konsistensi responden dalam menjawab instrument penelitian ini. Pengujian validitas dan reliabilitas dalam penelitian ini menggunakan alat bantu software Partial Least Square (SmartPLS versi 3.0).

Validitas konvergensi diukur dengan loading faktor indicator dari masing-masing konstruk. Hasil dari outer loading untuk melihat tingkat validitas indikator dengan nilai loading factor diatas 0,7 pada Gambar 3.

Tingkat validitas indikator akan didasarkan pada nilai loading factor dengan kriteria nilai diatas 0,7 . Tabel 1 berikut adalah hasil loading factor dari masing-masing indikator.

Tabel 1 Hasil Outer Loading (Mean, STDEV, T-Values)

\begin{tabular}{|c|c|c|c|c|}
\hline & ATU & ITU & PEOU & PU \\
\hline ATU 1 & 0,908 & & & \\
\hline ATU 2 & 0,865 & & & \\
\hline ITU 1 & & 0,885 & & \\
\hline ITU 2 & & 0,797 & & \\
\hline PEOU 1 & & & 0,740 & \\
\hline PEOU 2 & & & 0,792 & \\
\hline PEOU 3 & & & 0,735 & \\
\hline PU 1 & & & & 0,783 \\
\hline PU 2 & & & & 0,798 \\
\hline PU 3 & & & & 0,752 \\
\hline PU 4 & & & & 0,775 \\
\hline
\end{tabular}

Sumber: Hasil Output SmartPLS 3.0.

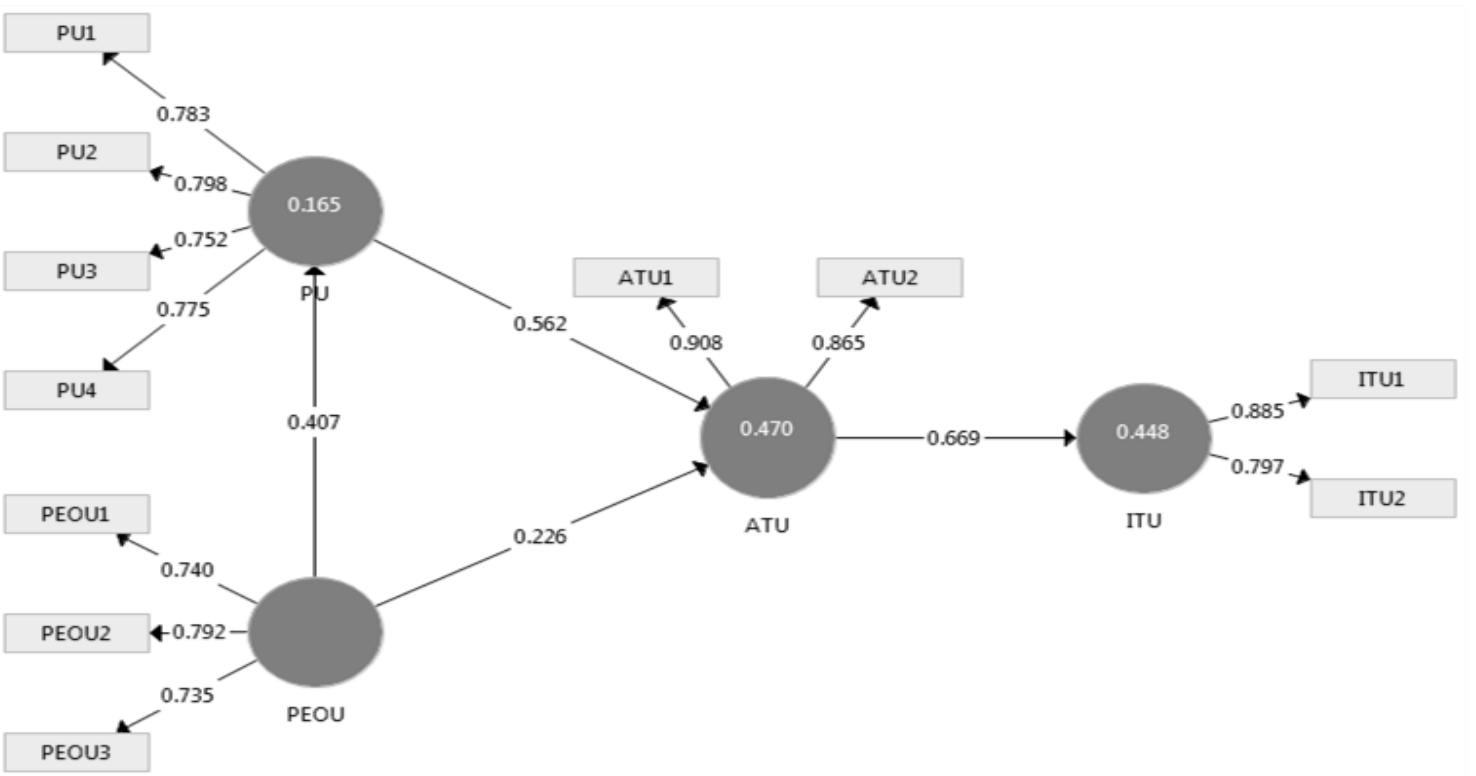

Gambar 3 Tampilan Output PLS Algorithm(Outer Model)

Sumber : Hasil Output SmartPLS 3.0 
Berdasarkan Gambar 3 dan Tabel 1 dapat dilihat bahwa nilai loading setiap indikator berada di atas 0,70, sehingga setiap indikator yang digunakan dikatakan valid.

Validitas diskriminan digunakan untuk menunjukkan bahwa konstruk laten dapat memprediksi ukuran pada blok mereka lebih baik daripada ukuran pada blok lainnya. Angka tercetak tebal pada Tabel 2 menunjukkan bahwa nilai korelasi indikator terhadap konstruknya (variabel laten) lebih besar dibandingkan dengan nilai korelasi antara indikator dengan konstruk lainnya.

Tabel 2. Hasil Outer Loading (Mean, STDEV, T-Values)

\begin{tabular}{|l|c|c|c|c|}
\hline & ATU & ITU & PEOU & PU \\
\hline ATU 1 & 0,908 & 0,671 & 0,459 & 0,584 \\
\hline ATU 2 & 0,865 & 0,504 & 0,338 & 0,577 \\
\hline ITU 1 & 0,630 & 0,885 & 0,379 & 0,570 \\
\hline ITU 2 & 0,485 & 0,797 & 0,131 & 0,309 \\
\hline PEOU 1 & 0,331 & 0,216 & 0,740 & 0,242 \\
\hline PEOU 2 & 0,306 & 0,210 & 0,792 & 0,234 \\
\hline PEOU 3 & 0,377 & 0,282 & 0,735 & 0,404 \\
\hline PU 1 & 0,478 & 0,408 & 0,401 & 0,783 \\
\hline PU 2 & 0,503 & 0,456 & 0,293 & 0,798 \\
\hline PU 3 & 0,426 & 0,411 & 0,306 & 0,752 \\
\hline PU 4 & 0,608 & 0,403 & 0,266 & 0,775 \\
\hline
\end{tabular}

Sumber: Hasil Output SmartPLS 3.0.

Pengujian validitas diskriminan juga dapat dilakukan dengan membandingkan akar AVE untuk setiap konstruk dengan korelasi antar konstruk lainnya dalam model. Nilai AVE dan akar AVE dari setiap konstruk ditunjukkan dalam Tabel 3 berikut.

Tabel 3. AVE dan Akar AVE

\begin{tabular}{|l|c|c|}
\hline & AVE & AKAR AVE \\
\hline PU & 0,604 & 0,777 \\
\hline PEOU & 0,572 & 0,756 \\
\hline ATU & 0,787 & 0,887 \\
\hline ITU & 0,709 & 0,842 \\
\hline
\end{tabular}

Sumber: Hasil Output SmartPLS 3.0.

Selanjutnya nilai akar AVE itu akan diperbandingkan dengan koefisien korelasi antar variabel, yang data hasilnya terlihat dalam Tabel 4.

Tabel 4. Variable Correlations dan Akar AVE

\begin{tabular}{|l|c|c|c|c|}
\hline & ATU & ITU & PEOU & PU \\
\hline ATU & 0,887 & & & \\
\hline ITU & 0,669 & 0,852 & & \\
\hline PEOU & 0,455 & 0,321 & 0,756 & \\
\hline PU & 0,654 & 0,539 & 0,407 & 0,777 \\
\hline
\end{tabular}

Sumber: Hasil Output SmartPLS 3.0.

Berdasarkan Tabel 4 yang menunjukkan hasil perbandingan antara nilai akar AVE dengan koefisien korelasi antar variabelnya maka perbandingan-perbandingan itu dapat menunjukkan bahwa pengukur (indikator) yang digunakan dalam penelitian ini telah memenuhi kriteria validitas diskriminan.

Reliabilitas suatu konstruk dapat dinilai dengan melihat nilai Cronbach's alpha dan Composite Reliability. Metode uji reliabilitas dalam penelitian ini adalah Composite Reliability karena lebih baik dalam mengestimasi konsistensi internal suatu konstruk 
(Werts dkk.., 1974 dalam Salisbury dkk.., 2002) yang dikutip Hartono dan Abdillah (2009). Rule of thumb nilai alpha atau Composite Reliability harus lebih besar dari 0,7 meskipun nilai 0,6 masih dapat diterima pada studi yang sifatnya eksploratory (Hair dkk..., 1998). Tabel 5. menunjukkan hasil uji reliabilitas konstruk, dimana masingmasing konstruk di atas 0,7 sehingga pengukur dalam penelitian ini reliable.

Model struktural dievaluasi dengan menggunakan $R$-Square untuk konstruk dependen, uji-t, serta signifikansi dari koefisien parameter jalur struktural. Tabel 6 menunjukkan R-Square yang perubahan nilainya akan digunakan untuk menilai pengaruh variabel laten independen tertentu dengan variabel laten dependen serta melihat adanya pengaruh substantif.

Tabel 5. Composite Reliability

\begin{tabular}{|l|c|}
\hline \multirow{2}{*}{ Konstruk } & Composite Reliability \\
\cline { 2 - 2 } & Kriteria $>0,7$ \\
\hline PU & 0,859 \\
\hline PEOU & 0,800 \\
\hline ATU & 0,880 \\
\hline ITU & 0,830 \\
\hline
\end{tabular}

Sumber: Hasil Output SmartPLS 3.0.

Tabel 6. R-Square

\begin{tabular}{|l|c|}
\hline & $R$-Square \\
\hline ATU & 0,470 \\
\hline ITU & 0,448 \\
\hline PU & 0,165 \\
\hline
\end{tabular}

Sumber: Hasil Output SmartPLS 3.0
Dari Tabel 6 dapat dilihat bahwa nilai R-Square untuk variabel Sikap yang Mengarahkan Penggunaan (ATU) adalah sebesar 0,470 yang berarti bahwa 47\% variance Sikap yang Mengarahkan Penggunaan (ATU) dijelaskan oleh variabel Persepsi Kegunaan (PU) dan Persepsi Kemudahan Penggunaan (PEOU), sedangkan sisanya 53\% dijelaskan oleh variabel lain di luar penelitian ini. Nilai R-Square untuk variabel Niat Perilaku untuk Menggunakan (ITU) adalah sebesar 0,448 yang artinya 44,8\% Niat Perilaku untuk Menggunakan mampu dijelaskan oleh variabel Sikap yang Mengarahkan Penggunaan (ATU) sedangkan lainnya sebesar $55.2 \%$ dijelaskan oleh variabel lain dari luar penelitian ini. Berikutnya untuk nilai R-Square variabel Persepsi Kegunaan (PU) yang bernilai 0,165 berarti bahwa 16,5\% variabel Persepsi Kegunaan dapat dijelaskan oleh variabel Persepsi Kemudahan Penggunaan (PEOU) sementara sisanya sebesar $83,5 \%$ dijelaskan oleh variabel lain dari luar penelitian ini.

Nilai T-statistic dalam tabel Path coefficient digunakan dalam model struktural untuk melihat hubungan antara variabel independen ke variabel dependen, sehingga dapat dinilai 
mengenai signifikansi model prediksi. Tabel 7 adalah hasil pengolahan data untuk uji signifikansi. Hasil pengolahan data PLS Algorithm ditunjukkan dengan Gambar 4.

Tabel 7. Path koefisien (Mean, STDEV, T Statistic)

\begin{tabular}{|l|c|c|c|c|}
\hline & $\begin{array}{c}\text { Origin } \\
\text { al } \\
\text { Sampl } \\
\text { e (O) }\end{array}$ & $\begin{array}{c}\text { Samp } \\
\text { le } \\
\text { Mean } \\
(\mathrm{M})\end{array}$ & $\begin{array}{c}\text { Standar } \\
\text { d } \\
\text { Deviati } \\
\text { on } \\
(\mathrm{STDE} \\
\mathrm{V})\end{array}$ & $\begin{array}{c}\mathrm{T} \\
\text { Statistic } \\
\mathrm{s} \\
(\mid \mathrm{O} / \mathrm{ST} \\
\mathrm{ERR} \mid)\end{array}$ \\
\hline $\begin{array}{l}\text { ATU -> } \\
\text { ITU }\end{array}$ & 0,669 & 0,661 & 0,069 & 9,725 \\
\hline $\begin{array}{l}\text { PEOU - } \\
>\text { ATU }\end{array}$ & 0,226 & 0,262 & 0,126 & 1,798 \\
\hline $\begin{array}{l}\text { PEOU - } \\
>\text { PU }\end{array}$ & 0,407 & 0,434 & 0,107 & 3,818 \\
\hline $\begin{array}{l}\text { PU -> } \\
\text { ATU }\end{array}$ & 0,562 & 0,532 & 0,123 & 4,570 \\
\hline STU
\end{tabular}

Sumber: Hasil Output SmartPLS 3.0

Dari hasil pengolahan data, pada tingkat siginifikansi 0,05 (t-statistik > ttabel 1,64) maka hipotesis 1 yang menyatakan bahwa tingkat kemudahan penggunaan teknologi dalam kegiatan akademik melalui SIAKAD dipersepsikan oleh seorang mahasiswa akan mempengaruhi secara positif pada kegunaan SIAKAD adalah signifikan dan terdukung. Hasil penelitian tersebut sejalan dengan temuan beberapa penelitian sebelumnya yaitu Calisir et.al.. (2009) mengatakan bahwa kegunaan mengacu pada sejauh mana sebuah situs web memfasilitasi pengguna untuk memanfaatkan fungsi dengan mudah dan tepat, serta temuan penelitian dari Pearson dan Green (2007) bahwa jika seorang pengguna menemukan situs yang sulit untuk digunakan (kegunaan), biasanya mereka tidak akan tetap pada situs tersebut untuk menentukan apakah isi (kegunaan) memenuhi persyaratan mereka. Definisi mudah itu adalah bebas dari kesulitan atau usaha yang besar, seperti menurut Davis (1989) bahwa persepsi kemudahan penggunaan

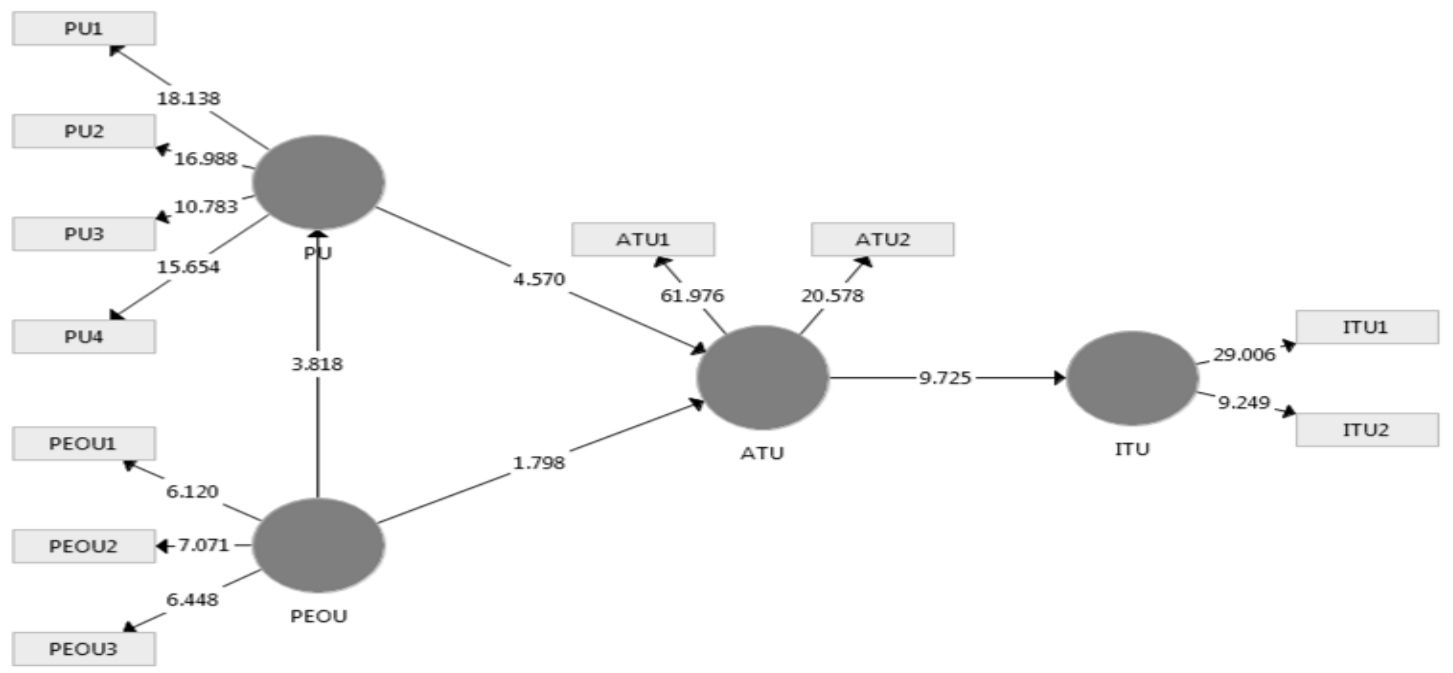

Gambar 4 Tampilan Output PLS Algorithm (Inner Model)

Sumber : Hasil Output SmartPLS 3.0 
mengacu pada derajat kepercayaan seseorang bahwa menggunakan sistem tertentu akan bebas dari suatu usaha.

Dari hasil pengolahan data itu dapat juga ditunjukkan bahwa tingkat kemudahan penggunaan teknologi dalam kegiatan akademik melalui SIAKAD dipersepsikan oleh seorang mahasiswa dan sikap mahasiswa yang mengarahkan penggunaan SIAKAD memiliki hubungan positif dan signifikan pada tingkat siginifikansi 0,05 (t-statistik>t-tabel 1,64), sehingga hipotesis 2 terdukung secara statistik oleh data yang diolah.Hasil penelitian mengenai adanya hubungan positif antara tingkat kemudahan penggunaan teknologi dalam kegiatan akademik melalui SIAKAD dipersepsikan oleh seorang mahasiswa dengan sikap mahasiswa yang mengarahkan penggunaan SIAKAD tersebut, sejalan dengan penelitian dari Dennis dkk. (2009) yaitu ketika pengguna merasa frustrasi karena kesulitan menggunakan sistem mereka menjadi bersikap negatif terhadap sistem.

Dari hasil pengolahan data itu dapat juga dilihat bahwa tingkat kegunaan dari SIAKAD dengan sikap yang mengarahkan penggunaan SIAKAD memiliki hubungan positif dan signifikan pada tingkat siginifikansi 0,05 (t-statistik>t-tabel 1,64), sehinggan hipotesis 3 terdukung secara statistik oleh data yang ada. Hasil penelitian ini sejalan dengan penelitian dari Moon dan Kim (2001) menyatakan bahwa persepsi kegunaan (Perceived Usefulness/ PU) memiliki pengaruh signifikan positif terhadap kepercayaan, sikap dan niat perilaku.

Dari hasil pengolahan data itu terlihat bahwa Sikap yang Mengarahkan Penggunaan SIAKAD seperti dipersepsikan oleh seorang mahasiswa dengan Niat Perilaku Menggunakan SIAKAD memiliki hubungan positif dan signifikan pada tingkat siginifikansi 0,05 (t-statistik>t-tabel 1,64), sehinggan hipotesis 4 terdukung secara statistik oleh data yang ada.

\section{SIMPULAN}

Dengan pembahasan yang telah dilakukan dapat disimpulkan.bahwa terdapat pengaruh yang positif dan signifikan antara variabel-variabel yang digunakan. Faktor-faktor penerimaan teknologi yang menimbulkan sikap mahasiswa untuk melakukan kegiatan akademik menggunakan SIAKAD adalah kemudahan (ease of use) dan kegunaan (usefulness). Mahasiswa akan melalukan kegiatan akademiknya 
dengan menggunakan SIAKAD adalah

karena merasa mendapatkan kemudahan dalam proses. Sementara persepsi kegunaan tanpa adanya kemudahan tidak akan menimbulkan niat mahasiswa untuk melakukan kegiatan akademiknya melalui SIAKAD. Penelitian ini masih dibatasi oleh variabel persepsi kemudahan penggunaan (Perceived Ease of Use), persepsi kegunaan (Perceived Usefulness), sikap yang mengarahkan penggunaan (Attitude Toward Using), dan niat perilaku menggunakan (Behavioral Intention To Use) saja sehingga masih dimungkinkan untuk memasukkan unsur variabel yang lain

\section{DAFTAR PUSTAKA}

Calisir, F., Gumussoy, C.A., Bayram, A., 2009, "Predicting the behavioral intention to use enterprise resource planning systems: An exploratory extension of the technology acceptance model", Management Research News, Vol. 32 Issue: 7, pp.597-613, https://doi.org/10.1108/01409170 910965215

Davis, F.D., 1989, Measurement Scales for Perceived Usefulness and Perceived Ease of Use, http://wings.buffalo.edu/mgmt/co urses/mgtsand/success/davis.html, (retrieved 23 Desember 2005)
Davis, F.D., 2000, Percieved Usefulness, Percieved Ease of Use, and User Acceptance of Information Technology. MIS Querterly, (Online), Vol 13, No. 3, pp. 319-340

Dennis, C., Jayawardhena, C., Merrilees, W. dan Wright, L. T., 2009, eConsumer Behaviour. European Journal of Marketing, Vol. 43, Nos. 9/10, pp. 11211139.

Fishbein, M., Azjen, 1975, Belief, Attitude, Intention and Behavior: An Introduction to Theory and Research. Reading, MA: Addison - Wesley

Ghozali, I., 2012, Structural Equation Modeling Metode Alternatif Dengan Partial Least Square (PLS). Badan Penerbit Universitas Diponegoro, Semarang.

Hartono, J., Abdillah, W., 2009, Konsep dan Aplikasi Partial Least Square (PLS) untuk Penelitian Empiris. Yogyakarta: Penerbit BPFE.

Hair, JF, Anderson RE Tatham, RL., 1998, Multivariate Analysis, 5 Edition, Prentice Hall International, Inc.

Jogiyanto, H.M., 2008, Metodologi Penelitian Sistem Informasi, Penerbit ANDI, Yogyakarta

Jogiyanto, H.M., Abdillah, W., 2010, Konsep dan Aplikasi PLS (Partial Least Square) untuk penelitian empiris, BPFE Yogyakarta, Yogyakarta

Kartika, 2013, Technology Acceptance Model: Menguji Keefektivan Penerimaan Sistem Informasi Terpadu (SISTER) di Lingkungan Universitas Jember, Universitas Jember, Jember. 
Lee, Younghwa, Kenneth A. Kozar, and Larsen, 2003, The Technology Acceptance Model: past, present, and future, Communication of the Association for Information System, 12(50:752-780).

Moon, J., Kim, Y., 2001, Extending the TAM for a World-Wide-Web context. Information and Management, 38, 217-230.

Mulyani, Asri, _, Analisis Penerimaan Teknologi Student Information Terminal (S-IT) dengan Menggunakan Technology Acceptance Model (TAM) (Studi Kasus: AMIK Garut), AMIK Garut.

Pearson, J.M., Pearson, A., Green, D., 2007, "Determining the importance of key criteria in web usability", Management Research News, Vol. 30 Issue: 11, pp.816828 ,

https://doi.org/10.1108/01409170 710832250

Petty, R. E., R. H. Unnava dan A. J. Strathman, A.J., 1991, Theories of Attitude Change', in T. S.
Robertson dan H. H. Kassarjian. (eds.) Handbook of

Consumer Behavior (PrenticeHall, Englewood Cliffs, NJ), pp. 241-280.

Sekundera P.L., Charlesto, 2006. Analisis Penerimaan Pengguna Akhir dengan Menggunakan Technology Acceptance Model dan End User Computing Satisfaction terhadap Penerapan Sistem Core Banking pada Bank $A B C$, Universitas Diponegoro, Semarang.

Soenhadji, Murtono, I., dkk, 2008, Prediksi Keyakinan Mahasiswa akan Manfaat Fasilitas Studentsite dengan Pendekatan Technology Acceptance Model. SNATI 2008

Supranto, J., 1981, Metode Riset: Aplikasi dalam Pemasaran, Lembaga, Penerbitan FE-UI, Jakarta.

Yanti ,S., 2012, Sikap Konsumen terhadap Teknologi Informasi Sebagai Pemoderasi Kepercayaan Belanja Online dengan Niat Belanja Kembali, STMIK EL RAHMA, Yogyakarta. 